\title{
Antimicrobial sensitivity of Listeria monocytogenes isolated from beef
}

Sensibilidade antimicrobiana de Listeria monocytogenes isolada de carne bovina

\section{Rodolfo Nunes de Almeida ${ }^{1}$, Ana Cláudia Chesca ${ }^{2}$, Aparecida Donizetti da Silva ${ }^{3}$, Erika Cecília Vallim Severino ${ }^{4}$, Otávio Augusto Martins ${ }^{5}$, Fernanda Raghiante $^{6^{*}}$}

\begin{abstract}
The objective of this study was to investigate the antimicrobial susceptibility of Listeria monocytogenes previously isolated from beef. The experiment used ground beef, commercialized in the city of Uberaba, Minas Gerais, Brazil. Using the Kirby-Bauer method, analyzes of antimicrobial susceptibility were carried out in the 14 isolates of Listeria monocytogenes. All strains (100\%) showed sensitivity to antimicrobials: amoxicillin, ampicillin, gentamicin, penicillin, teicoplanin and vancomycin; Six strains $(42.86 \%)$ presented sensitivity to sulfamethoxazole / trimethoprim and tetracycline; 3 strains (21.43\%) presented sensitivity to erythromycin and 2 strains (14.29\%) showed sensitivity to ciprofloxacin. While 8 strains $(57.14 \%)$ presented intermediate resistance to ciprofloxacin and tetracycline. All strains isolated showed resistance to cefazolin, cefepime, cefotaxime, clindamycin, oxacillin and polymyxin $b$. The antimicrobial resistance of Listeria monocytogenes poses serious risks to public health, due to its seriousness in affecting vulnerable segments of the human population, due to the wide presence of this bacterium in the environment, being isolated from food processing environments, water effluents to industries and causing possible contamination of various foodstuffs.
\end{abstract}

Index terms: Listeriosis, food safety, public health.

Resumo: O objetivo deste estudo foi investigar a sensibilidade antimicrobiana de Listeria monocytogenes previamente isolada de carne bovina. O corte de carne bovina usada no experimento foi acém, moído, comercializado no município de Uberaba, Minas Gerais, Brasil. Utilizando o método de Kirby-Bauer, foram realizadas nas 14 cepas isoladas de Listeria monocytogenes as análises de suscetibilidade aos antimicrobianos. Todas as cepas (100\%) apresentaram sensibilidade aos antimicrobianos: amoxicilina, ampicilina, gentamicina, penicilina, teicoplanina e vancomicina; 6 cepas $(42,86 \%)$ apresentaram sensibilidade ao sulfametoxazol/trimetoprim e tetraciclina; 3 cepas $(21,43 \%)$ apresentaram sensibilidade a eritromicina e 2 cepas $(14,29 \%)$ apresentaram sensibilidade a ciprofloxacina. Enquanto que 8 cepas $(57,14 \%)$ apresentaram resistência intermediária a ciprofloxacina e tetraciclina. Todas as cepas isoladas apresentaram resistência a cefazolina, cefepime, cefotaxima, clindamicina, oxacilina e polimixina b. A resistência antimicrobiana de Listeria monocytogenes ocasiona sérios riscos à saúde pública, por sua gravidade em acometer segmentos vulneráveis da população humana, pela ampla presença desta bactéria no ambiente, sendo isolada de ambientes de processamento alimentar, efluentes de água para indústrias e por ocasionar eventual contaminação de diversos gêneros alimentícios.

Termos para indexação: Listeriose, segurança alimentar, saúde pública.

Corresponding author: E. Mail: * fernanda.raghiante@iftm.edu.br

Recebido em 10.03.2018. Aceito em 30.06.2018

http://dx.doi.org/10.5935/1981-2965.20180025

${ }^{1}$ Especialista, Instituto Federal de Educação, Ciência e Tecnologia do Triângulo Mineiro (IFTM), Campus

Uberlândia, Minas Gerais, Brasil. E-mail: rodolfonunes@edu.uniube.br

${ }^{2}$ Doutorado, Universidade de Uberaba (UNIUBE), Uberaba, Minas Gerais, Brasil. E-mail:

ana.chesca@uniube.br

${ }^{3}$ Graduação, Universidade de Uberaba (UNIUBE), Uberaba, Minas Gerais, Brasil. E-mail: 
Almeida et al., Revista Brasileira de Higiene e Sanidade Animal (v.12, n.3) p. 254 - 261 jul - set (2018)

aparecida.microbiologia@uniube.br

${ }^{4}$ Graduação, Universidade de Uberaba (UNIUBE), Uberaba, Minas Gerais, Brasil. E-mail:

erika_vallim@hotmail.com

${ }^{5}$ Pós-Doutorado, Faculdade de Medicina Veterinária e Zootecnia, Universidade Estadual Paulista (UNESP),

Campus de Botucatu, São Paulo, Brasil. E-mail: oamartins@ fmvz.unesp.br

${ }^{6}$ Doutorado, Instituto Federal de Educação, Ciência e Tecnologia do Triângulo Mineiro (IFTM), Campus

Uberlândia, Minas Gerais, Brasil. *E-mail: fernanda.raghiante@iftm.edu.br

\section{Introduction}

High humidity, near-neutral $\mathrm{pH}$, nutrientrich composition, increased surface area and high handling rate during processing give the milled beef an excellent bacterial growth potential by favoring the installation, survival and the multiplication of pathogenic microorganisms, such as Listeria monocytogenes, capable of reproducing under refrigeration temperature due to its psychrotrophic characteristics (Jay, 2005; Mantilla et al., 2007; Forsythe, 2013). For this reason, this bacterium can be found frequently in many food products and processing plants as a constituent of biofilms (Filgueiras \& Vanetti, 2006, FDA, 2017).

Food-borne listeriosis is a relatively rare and serious disease with a high mortality rate of $20 \%$ to $30 \%$ produced by opportunistic infection with Listeria monocytogenes, affecting specific segments of the population that have some type of impairment in the immune system (FAO WHO, 2004, FDA, 2017). Symptoms such as febrile gastroenteritis in healthy adults after ingestion of large numbers of L. monocytogenes cells are common (Bhat et al., 2012).

The incubation period of $L$. monocytogenes varies between 10 and 70 days after oral contamination. The first clinical signs appear unspecific and are constantly confused with flu symptoms. However, gastroenteritis, endocarditis, pneumonia, vomiting, arthritis, ocular diseases, hepatitis, cramps and lack of appetite may occur (Lecuit, 2007; Forsythe,
2013). Cases where the infection manifests itself systemically and reaches the host's nervous system, there are cases of meningitis, encephalitis and abscesses, whereas in pregnant women premature birth, fetal malformations, neonatal sepsis, spontaneous abortion and stillbirth may occur (Franco \& Landgraf, 2008, Tortora, 2016).

Many bacterial species can develop resistance to antibiotics to which they are exposed due to the use in clinical and veterinary areas. In general, it occurs due to random mutations with consequent positive selection of antimicrobial resistant mutants, mobilization and sharing by resistance gene transfer and dissemination of strains that have developed previous resistance (Tortora, 2016; Forsythe, 2013). However, in recent years there has been an increase in the scientific reports of L. monocytogenes strains, although they have a natural resistance to fosfomycins and cephalosporins resistant to antimicrobials (FDA, 2017).

Considering the high associated mortality rate, the emergence and spread of antimicrobial resistance in $L$. monocytogenes can generate significant clinical implications for the treatment of listeriosis (Conter et al., 2009). Given the importance of this microorganism to public health, the objective of this work was to investigate the antimicrobial profile of 14 strains of Listeria monocytogenes previously isolated from samples of ground beef sold in the city of Uberaba-MG.

\section{Material and Methods}


Almeida et al., Revista Brasileira de Higiene e Sanidade Animal (v.12, n.3) p. 254 - 261 jul - set (2018)

\section{Samples}

Thirty samples of fresh ground beef, randomly collected from meat retailers in the city of Uberaba-MG, were used. Sample temperature data were collected at the time of collection. The samples were transported in an isothermal box containing reusable ice until it was received at the Food Microbiology Laboratory of the University of Uberaba (UNIUBE), Minas Gerais, Brazil.

Listeria monocytogenes research

To investigate L. monocytogenes, the direct plating methodology described by Silva et al. (2017). The isolated strains were phenotypically confirmed by BAM / FDABacteriological Analytical Manual / Food and Drug Administration (2001) and stored at $-80^{\circ} \mathrm{C}$ in cryogenic tubes containing $2 \mathrm{~mL}$ of $50 \%$ BHI (Brain Heart Infusion) solution and glycerol, time of antimicrobial susceptibility testing.

\section{Antimicrobial susceptibility}

After slow thawing, the previously isolated and identified strains of $L$. monocytogenes were reactivated by culture in TSB-YE broth (Trypticase Soy Broth supplemented with $0.6 \%$ Yeast Extract) at $35^{\circ} \mathrm{C}$ for $24 \mathrm{~h}$, then pealed at 5\% sheep blood agar (Mueller Hinton Agar) for 24 hours at $35^{\circ} \mathrm{C}$.

According to guidelines of the Clinical and Laboratory Standards Institute (CLSI M45A3, 2015) and European Committee on Antimicrobial Susceptibility Testing (EUCAST, 2017), using the Kirby-Bauer (1996) method on $5 \%$ the susceptibility analyzes of $L$. monocytogenes strains to antimicrobials were carried out: amoxicillin $10 \mathrm{mcg}$, ampicillin $10 \mu \mathrm{g}$, cefazolin $30 \mathrm{mcg}$, cefepime $30 \mu \mathrm{g}$, cefotaxime 30 $\mu \mathrm{g}$, ciprofloxacin $05 \mu \mathrm{g}$, clindamycin $02 \mu \mathrm{g}$, erythromycin $15 \mathrm{mcg}$, gentamicin $10 \mu \mathrm{g}$, oxacillin
$01 \mu \mathrm{g}$, penicillin $\mathrm{g}$ (benzylpenicillin) $10 \mu \mathrm{l}$, polymyxin b $300 \quad \mu \mathrm{g}$, sulfamethoxazole / trimethoprim 1.25 / $23.75 \mu \mathrm{g}$ (sulfazotrim $25 \mu \mathrm{g}$ ), teicoplanin $30 \mu \mathrm{g}$, tetracycline $30 \mu \mathrm{g}$ and vancomycin $30 \mu \mathrm{g}$.

For the positive control of the culture medium and the halos, an antimicrobial susceptibility test (antibiogram) was performed on a Streptococcus pneumoniae strain ATCC 49619.

After the incubation period at $35^{\circ} \mathrm{C}$ for 24-48hs, the reading and interpretation of the results in sensitive, intermediate or resistant were performed according to the break points for the measurement of the size of the specific halos for L. monocytogenes described by EUCAST (2017) for penicillin $\mathrm{g}$, ampicillin, erythromycin and sulfamethoxazole / trimethoprim, whereas for the other antimicrobials, due to lack of standardization in susceptibility criteria for $L$. monocytogenes, cut-off points were used according to CLSI recommendations M100-S26 (2016) for Staphylococcus spp., with the exception of vancomycin, which was used in the 2012 CLSI table (M100-S22).

\section{Data analysis}

The data analysis of this work to evaluate the antimicrobial susceptibility of $L$. monocytogenes previously isolated from bovine milled samples used Microsoft Excel and Microsoft Word. It is worth noting that the statistical analysis using the Anova methodology complemented with the Tukey test was not applied in this type of study. Results were expressed as percentages.

\section{Results and discussion}

Listeria monocytogenes was isolated in 14 $(46.66 \%)$ of the total of 30 samples of ground 
Almeida et al., Revista Brasileira de Higiene e Sanidade Animal (v.12, n.3) p. 254 - 261 jul - set (2018)

beef analyzed. The sensitivity profile of these strains to the various antimicrobials evaluated is shown in Table 1.

Regarding intermediate resistance, $57.14 \%(\mathrm{n}=8)$ of the strains isolated in this study had intermediate resistance to cirpofloxacin and tetracycline.
Resistance to cephalosporins is reported by EUCAST (2017) as the specific natural resistance of $L$. monocytogenes, while resistance to polymyxin $b$ is reported by the Comité de L'antibiogramme de La Société Française de Microbiologie (2016) as the natural resistance of Gram bacilli and oxacillin as specific for $L$. monocytogenes.

Table 1. Antimicrobial susceptibility and resistance profile of L. monocytogenes strains isolated from ground beef.

\begin{tabular}{lcc}
\hline Antimicrobial & Susceptibility \% & Resistance \\
& $(\mathbf{n})$ & $\%(\mathbf{n})$ \\
\hline Amoxicilin $10 \mathrm{mcg}$ & $100(14)$ & $0(0)$ \\
Ampicilin $10 \mu \mathrm{g}$ & $100(14)$ & $0(0)$ \\
Cefazolin $30 \mathrm{mcg}$ & $0(0)$ & $100(14)$ \\
Cefepime $30 \mu \mathrm{g}$ & $0(0)$ & $100(14)$ \\
Cefotaxime $30 \mu \mathrm{g}$ & $0(0)$ & $100(14)$ \\
Ciprofloxacin $05 \mu \mathrm{g}$ & $14,29(2)$ & $28,57(4)$ \\
Clindamycin $02 \mu \mathrm{g}$ & $0(0)$ & $100(14)$ \\
Eritromycin $15 \mathrm{mcg}$ & $21,43(3)$ & $78,57(11)$ \\
Gentamicin $10 \mu \mathrm{g}$ & $100(14)$ & $0(0)$ \\
Oxacilin $01 \mu \mathrm{g}$ & $0(0)$ & $100(14)$ \\
Penicilin $10 \mathrm{UI}$ & $100(14)$ & $0(0)$ \\
Polimyxin B $300 \mu \mathrm{g}$ & $0(0)$ & $100(14)$ \\
Sulfamethoxazole / Trimethoprim $1,25 / 23,75 \mu \mathrm{g}$ & $42,86(6)$ & $57,14(8)$ \\
Teicoplanin $30 \mu \mathrm{g}$ & $100(14)$ & $0(0)$ \\
Tetracycline $30 \mathrm{mcg}$ & $42,86(6)$ & $0(0)$ \\
Vancomycin $30 \mu \mathrm{g}$ & $100(14)$ & $0(0)$ \\
\hline
\end{tabular}

The results of this work, obtained from the analyzes of the 14 isolates of $L$. monocytogenes, are consistent with similar reports in the published scientific literature, such as Hernández \& Hernández-Godoy (2004), analyzing the antimicrobial profile of 30 strains of L. monocytogenes isolated in the province of Valencia between 1998 and 2003 from foods of animal origin (fresh meat, fresh sausage, fresh sausages, hamburgers, meatballs and cooked ham ) for human consumption showed sensitivity to all antibiotics $(30 \mu \mathrm{g}$ amikacin, $30 \mu \mathrm{g}$ amoxicillin-clavulanic, $10 \mu \mathrm{g}$ ampicillin, $30 \mu \mathrm{g}$ cephalothin, $5 \mu \mathrm{g}$ ciprofloxacin, $30 \mu \mathrm{g}$ chloramphenicol, $15 \mu \mathrm{g}$ erythromycin, $10 \mu \mathrm{g}$ streptomycin, $10 \mu \mathrm{g}$ gentamycin, kanamycin 30 
Almeida et al., Revista Brasileira de Higiene e Sanidade Animal (v.12, n.3) p. 254 - 261 jul - set (2018)

$\mu \mathrm{g}$, nitrofurantoin $300 \mu \mathrm{g}$, penicillin $\mathrm{G} 10 \mu \mathrm{g}$, tetracycline $30 \mu \mathrm{g}$, ticarcillin $75 \mu \mathrm{g}$, tobramycin $10 \mu \mathrm{g}$, sulfamethoxazole / trimethoprim $1.25 \pm$ $23.75 \mu \mathrm{g}$ and vancomycin $30 \mu \mathrm{g}$ ), with the exception of one strain $(3.33 \%)$, which was resistant to tetracycline.

Similarity also found by Ennaji et al. (2008) in 10 strains of L. monocytogenes isolated from raw ground red meat, meat products (sausages) and raw farmed poultry in Morocco, found sensitivity to amoxicillin, ticarcillin, gentamicin, tobramycin, amikacin, chloramphenicol, penicillin and ampicillin and resistance nalidixic acid, colistin and second and third cephalosporins generation.

However, Mantilla et al. (2008), analyzing the antimicrobial profile in L. monocytogenes strains from ground beef samples, found $100 \%$ antimicrobial resistance clindamycin, oxacillin, gentamicin, sulfazotrim, cefoxitin and ampicillin, 83.3\% erythromycin, $66.7 \%$ to tetracycline, penicillin, cephalothin and ciprofloxacin and 50\% resistance to amikacin, vancomycin, chloramphenicol and rifampicin. They also reported that $16.7 \%$ of strains presented an intermediate profile to ciprofloxacin, chloramphenicol and rifampicin and sensitivity to erythromycin and ciprofloxacin; sensitivity to tetracycline, penicillin, cephalothin, chloramphenicol and rifampicin in $33.3 \%$ and amikacin and vancomycin in $50 \%$ of $L$. monocytogenes strains isolated in the study.

Chen et al. (2010) in 86 strains of $L$. monocytogenes isolated from fresh catfish fillets and their processing facilities (processing facilities - aquarium and water, food contact surfaces and instruments, and floor) found resistance to cefotaxime in $71 \% \quad(\mathrm{n}=61)$ and clindamycin in $69 \%(n=59)$, intermediate profile to cefotaxime in $29 \%(\mathrm{n}=25)$, clindamycin $31 \%$ $(\mathrm{n}=27)$ and penicillin $83 \% \quad(\mathrm{n}=71)$ and streptomycin in $2 \% \quad(\mathrm{n}=2)$ and penicillin sensitivity in $17 \% \quad(n=15)$, streptomycin $98 \%$ $(n=84)$ and ampicillin, cephalothin, chlorafenicol, erythromycin, gentamicin, kanamycin, oxytetracycline, rifampicin, tetracycline, sulfamethoxazole / trimethoprim and vancomycin in $100 \%(\mathrm{n}=86)$.

Khen et al. (2014) investigated $L$. monocytogenes strains isolated from meat chain samples (bovine hides, precooled carcasses and ground beef) in Ireland, where a small portion $(<5 \%)$ of the isolates showed resistance to antimicrobials including ampicillin, vancomycin and gentamicin, which are the recommended treatment options for listeriosis.

Palma et al. (2016), analyzing the antimicrobial profile of 11 strains of $L$. monocytogenes isolated from bovine meat cuts and 2 strains of cattle slaughterhouse environments in the Federal District, identified $100 \%$ of strains isolated from beef cattle cuts $(\mathrm{n}=11)$ sensitivity to amoxicillin, cephalosporins, chloramphenicol, penicillin, tetracycline and vancomycin, norfloxacin $81.8 \% \quad(\mathrm{n}=9)$, erythromycin and gentamicin $90.9 \% \quad(\mathrm{n}=10)$, $63.6 \%(\mathrm{n}=7)$ a ciprofloxacin and sulphonamides $27.3 \%(n=3)$, reported intermediate profile to ciprofloxacin in $27.3 \%(\mathrm{n}=3)$ and norfloxacin $18.2 \%(\mathrm{n}=2)$ in $100 \%(\mathrm{n}=11)$ showed resistance to nalidixic acid, in $72.7 \%(\mathrm{n}=8)$ the sulfonamides and in $9.1 \%(\mathrm{n}=1)$ resistance to ciprofloxacin, erythromycin and gentamicin. In another study, evaluating strains isolated from cattle slaughtering environments (drainage streams), the same 
Almeida et al., Revista Brasileira de Higiene e Sanidade Animal (v.12, n.3) p. 254 - 261 jul - set (2018)

authors identified that $100 \%$ of them had sensitivity to amoxicillin, cephalosporins, chloramphenicol, erythromycin, gentamicin, norfloxacin, penicillin, tetracycline and vancomycin and $50 \%$ to ciprofloxacin.

Concern about human listeriosis caused by antimicrobial resistant $L$. monocytogenes is due to its ability to infect susceptible (immunocompromised) populations through the diet and may become invasive, causing several complications (Jay, 2005). In this sense, Bhat et al. (2012) investigated the antimicrobial profile of L. monocytogenes strains isolated from 60 human samples of blood and cerebrospinal fluid in patients with encephalitis and meningitis and observed sensitivity in $100 \%$ of the isolates for gentamicin, doxycycline, ciprofloxacin and ceftriaxone, $50 \% \quad(100 \%)$ and ampicillin /cloxacillin (100\%), while all strains isolated were resistant to ampicillin, oxytetracycline, amoxicillin, streptomycin, amikacin,

\section{References}

1. BHAT, S.A.; WILLAYAT, M.M.; ROY, S.S.; BHAT, M.A.; SHAH, S.N.; AHMEID, A.; MAQBOOL, S.; GANAYI, B.A. Isolation, molecular detection and antibiogram of Listeria monocytogenes from human clinical cases and fish of Kashmir, India. Comparative Clinical Pathology, v. 22, n. 4, p. 661-665, 2013.

2. CHEN, B.- Y; PYLA, R.; KIM, T.-J.; SILVA, J.L.; JUNG, Y.-S. Antibiotic resistance in Listeria species isolated from catfish fillets and processing environment. Letters in applied microbiology, v. 50, n. 6, p. 626-632, 2010.

3. CLSI, Clinical and Laboratory Standards Institute. Methods for Antimicrobial Dilutions and Disk Susceptibility Testing of Infrequently Isolated or Fastidious Bacteria (M45-A3), 3.ed. CLSI guideline cefpodoxime, erythromycin, norfloxacin, and cefalexin. cefotaxime.

Listeria spp. (including $L$. monocytogenes) are widely distributed in nature and may be found in soil, human and animal fecal material, sewage, river water, slaughterhouse effluent, food processing environments, poultry, fish and domestic animals. eventually contaminate food (Tortora, 2016).

\section{Conclusion}

Listeria monocytogenes present in food can pose serious public health risks. This fact is aggravated when this microorganism presents resistance to several antimicrobials used in the conventional treatment of people affected by listeriosis. Effective control of the quality of food production, especially of animal origin, is extremely important in the prevention of food infections.

M45. Wayne, PA: Clinical and Laboratory Standards Institute, 2015.

4. CLSI, Clinical and Laboratory Standards Institute. Performance Standards for Antimicrobial Susceptibility Testing (M100-S26). 26. ed. CLSI supplement M100S. Wayne, PA: Clinical and Laboratory Standards Institute, 2016.

5. CLSI, Clinical and Laboratory Standards Institute. Performance Standards for Antimicrobial Susceptibility Testing (M100-S22). 22. ed. CLSI supplement M100S. Wayne, PA: Clinical and Laboratory Standards Institute, 2012.

6. COMITÉ DE L'ANTIBIOGRAMME DE LA SOCIÉTÉ FRANÇAISE DE MICROBIOLOGIE. Recomendations 2016: Version 1.0 de Février, France 2016. 
Available in: $\quad<$ http://www.sfmmicrobiologie.org>. Acesso em: 01/01/2017.

7. CONTER, M.; PALUDI, D.; ZANARDI, E.; GHIDINI, S.; VERGARA, A.; IANIERI, A.

Characterization of antimicrobial resistance of foodborne Listeria monocytogenes. International Journal of Food Microbiology, v.128, n.3, p.497-500, 2009.

8. ENNAJI, H.; TIMMINOINI, M.; ENNAJI, M.M.; COHEN, N. Characterization and antibiotic susceptibility of Listeria monocytogenes isolated from poultry and red meat in Morocco. Infection and Drug Resistance, v. 1, p. 45-50, 2008.

9. EUCAST, European Committee on Antimicrobial Susceptibility Testing et al. Breakpoint tables for interpretation of MICs and zone diameters: Version 7.0, valid from 2017-01-01, 2017. Available in:< http://www.eucast.org>. Accessed in: 01/01/2017.

10. FAO \& WHO, Food and Agriculture Organization and World Health Organization. Risk Assessment of Listeria monocytogenes in Ready-to-Eat Foods, Microbiological Risk Assessment Series 4, Interpretive Summary, 2004. Available in: $<$ http://apps.who.int/iris/bitstream/10665/428 74/1/9241562617.pdf?ua=1>. Accessed in: 27 jul. 2016. ISBN 978-92-5-105762-9

11. FDA, Food and Drug Administration. U.S. Department of Health and Human Services. Center for Food Safety and Applied Nutrition. Draft Guidance for Industry: Control of Listeria monocytogenes in Ready-To-Eat Foods, 2017. Available in: $<$ http://www.fda.gov/Food/GuidanceRegulati on/GuidanceDocumentsRegulatoryInformatio n/ucm073110.htm?source=govdelivery\&utm medium=email\&utm_source=govdelivery $>$. Accessed in: 13/02/2017.

12. FILGUEIRAS, C. T.; VANETTI, M. C. D. Effect of eugenol on growth and listeriolysin o production by Listeria monocytogenes. Brazilian Archives of
Biology and Technology, Curitiba, v. 49, n. 3, p. 405-409, 2006.

13. FORSYTHE,

STEPHEN J. Microbiologia da segurança dos alimentos. 2.ed. Porto Alegre: Artmed, 2013. $620 \mathrm{p}$.

14. FRANCO, B.D.G.M.; LANDGRAF, M. Microbiologia dos Alimentos. São Paulo: Editora Atheneu, 2008. p.182.

15. HERNÁNDEZ, BALTASAR BALSALOBRE; HERNÁNDEZ-GODOY, JOAQUÍN. Resistencias a antibióticos en Listeria monocytogenes y Salmonella enterica aislados de alimentos de origen animal. Revista de Salud Ambiental, v. 4, n. 1-2, p. 42-46, 2004.

16. JAY, J. M. Listerioses de origem animal. In: Microbiologia de alimentos. 6. ed. Porto Alegre: Artmed, 2005. cap. 25 , p. 517-542, 711 p.

17. KHEN, B. K., LYNCH, O. A., CARROLL, J., MCDOWELL, D. A. and DUFFY, G. (2015), Occurrence, Antibiotic Resistance and Molecular Characterization of Listeria monocytogenes in the Beef Chain in the Republic of Ireland. Zoonoses Public Health, 62: 11-17. doi:10.1111/zph.12106

18. LECUIT, M. Human Listeriosis and Animal Models. Microbes and Infeccion. v.9, p.1216-1225, 2007.

19. MANTILLA, S. P. S.; FRANCO, R.M.; OLIVEIRA, L.A.T.; SANTOS, E.B.; GOUVÊA, R. Ocorrência de Listeria spp. em amostras de carne bovina moída comercializadas no município de Niterói, RJ, Brasil. Ciência e Agrotecnologia, Lavras, v.31, n.4, p.1225-1230, 2007.

20. MANTILLA, S. P. S.; FRANCO, R.M.; OLIVEIRA, L.A.T.; SANTOS, E.B.; GOUVÊA, R. Resistência antimicrobiana de bactérias do gênero Listeria spp: isoladas de carne moída bovina. Brazilian Journal of Veterinary Research and Animal Science, v. 45, n. 2, p. 116-121, 2008. 
21. PALMA, J.M.; LISBOA, R.C.; RODRIGUES, D.P.; SANTOS, A.F.M.; HOFER, E.; SANTANA, A.P. Caracterização molecular de Listeria monocytogenes oriundas de cortes cárneos bovinos e de abatedouros frigoríficos de bovinos localizados no Distrito Federal, Brasil. Pesquisa Veterinária Brasileira, v. 36, n. 10, p. 957-964, 2016.

22. SILVA, N.; JUNQUEIRA, V.C.A.; SILVEIRA, N.F.A.; TANIWAKI, N.H.; GOMES, R.A.R.; OKASAKI, M.M. Manual de Métodos de Análise Microbiológica de Alimentos e Água. 5. ed. São Paulo: Livraria Blucher, 2017. 560p.

23. TORTORA, G.J.; CASE, C.L.; FUNKE, B.R. Microbiologia. 12. ed. Porto Alegre: Artmed Editora, 2016. 964p. 